\title{
PENINGKATAN KOMPETENSI GURU SD DALAM MENYUSUN RPP DAN MELAKSANAKAN PEMBELAJARAN MENGGUNAKAN TUTOR SEJAWAT
}

\author{
Hanifah Kusumawati \\ hanifahkusumawati91@gmail.com \\ Program Pascasarjana Magister Manajemen Pendidikan \\ FKIP - Universitas Kristen Satya Wacana
}

\begin{abstract}
ABSTRAK
Penelitian ini berangkat dari hasil supervisi tentang adanya permasalahan kompetensi guru dalam menyusun Rencana Pelaksanaan Pembelajaran (RPP) belum memadai (baru mencapai 59,375\%); Demikian juga kompetensi guru dalam melaksanakan pembelajaran baru mencapai 60,8. Kondisi devisit kompetensi guru yang cukup tinggi ini (40,625\% dan 39,2\%) merupakan kebutuhan guru akan pelayanan dari Kepala Sekolah selaku supervisor dalam memberikan penilaian dan masukan terhadap keterampilan guru dalam menyusun dan mengimplementasikan Rencana Pelaksanaan Pembelajaran (RPP). Tujuan penelitian tindakan sekolah ini untuk meningkatkan keterampilan guru dalam menyusun dan mengimplementasikan RPP. Subjek penelitian ini adalah 4 guru SDIT AL-Fallah Kecamatan Simo, Kabupaten Boyolali. Penelitian ini merupakan penelitian tindakan sekolah yang terdiri dari dua siklus. Instrumen penelitian menggunakan lembar observasi dan panduan wawarcara. Hasil penelitian ini menunjukkan adanya peningkatan keterampilan guru dalam menyusun dan mengimplementasikan RPP. Pada Siklus I, meskipun belum tuntas (kriteria PTS berhasil jika terjadi peningkatan kompetensi guru $\chi 30 \%$ ), namun terjadi peningkatan kompetensi guru dalam menyusun RPP sebesar 25\% dan peningkatan kompetensi dalam melaksanakan pembelajaran sebesar 26\%. Pada Siklus II peningkatan kompetensi guru sudah tuntas (kriteria PTS berhasil jika terjadi peningkatan kompetensi guru $\geq 25 \%$ ), hasil penelitian menunjukkan terjadi peningkatan kompetensi guru dalam menyusun RPP sebesar $26 \%$ dan peningkatan kompetensi dalam melaksanakan pembelajaran sebesar $25 \%$.
\end{abstract}

Kata kunci: Kemampuan Guru, Supervisi Klinis.

\section{PENDAHULUAN}

Guru merupakan salah satu faktor yang memegang peran penting terhadap mutu pendidikan. Pendidikan yang bermutu ditandai dengan keberhasilan proses pembelajaran di sekolah. Jika guru dapat mengelola kelas dan memberikan layanan belajar dengan baik, maka kegiatan pembelajaran di sekolah akan berhasil. Dengan kata lain, keberhasilan suatu proses pembelajaran tidak terlepas dari aktivitas guru. Aktivitas guru yang akan memberikan layanan belajar yang berkualitas tentu membutuhkan pemahaman akan konsep belajar dan pengembangan kurikulum dalam bentuk penyusunan silabus, Rencana Pelaksanaan Pembelajaran (RPP), dan implementasinya dalam kegiatan pembelajaran baik di dalam maupun di luar kelas (Sagala, 2012: 32). 
Hal tersebut sesuai dengan Permendiknas Nomor 41 Tahun 2007 tentang standar proses untuk satuan pendidikan dasar dan menengah, bahwa dalam proses pembelajaran diperlukan perencanaan, pelaksanaan, penilaian, dan pengawasan. Perencanaan proses pembelajaran salah satunya adalah penyusunan silabus yang kemudian akan dijabarkan dalam RPP sebagai pedoman guru dalam melaksanakan proses pembelajaran.

Oleh sebab itu, setiap guru pada satuan pendidikan diwajibkan untuk menyusun RPP secara lengkap dan sistematis agar pembelajaran berlangsung secara interaktif, inspiratif, menyenangkan, menantang, memotivasi peserta didik untuk berpartisipasi aktif, serta memberikan ruang yang cukup bagi prakarsa, kreativitas, dan kemandirian sesuai dengan bakat, minat, dan perkembangan fisik serta psikologis peserta didik. Dengan demikian, penyusunan dan implementasi RPP oleh guru, perlu di fasilitasi dan dibimbing oleh kepala sekolah dan pengawas untuk meningkatkan kualitas pembelajaran (Sagala, 2012: 35).

Bertitik tolak dari pemikiran di atas bahwa penyusunan RPP itu wajib dan dibutuhkan sebagai pedoman mengajar, maka dilakukan studi pendahuluan di SDIT Al-Fallah Simo. Hasil studi pendahuluan diperoleh data sebagai berikut: 1) skor rata-rata kemampuan guru dalam menyusun RPP hanya sebesar 59 (berada pada kategori cukup); 2) skor rata-rata kemampuan dalam melakukan pembelajar-an sebesar 60,8 (berada pada kategori cukup).

Berangkat dari hasil studi pendahuluan, yang menunjukan adanya kebutuhan guru akan pelayanan supervisor, maka dibutuhkan adanyasuatu upaya yang bertujuan untuk memperbaiki kelemahan-kelemahan guru dalam menyusun dan mengimplementasikan RPP, sehingga dapat meningkatkan kualitas pembelajaran yang pada akhirnya mampu mempengaruhi hasil belajar peserta didik. Menurut Pidarta (2009: 124) permasalahan kinerja guru yang dirasa masih amat lemah dapat diatasi menggunakan supervisi klinis. Sejalan dengan gagasan Pidarta, Sagala (2012: 194) mengungkapkan salah satu upaya yang dapat dilakukan untuk memperbaiki kelemahan guru adalah melalui supervisi klinis.

Supervisi klinis merupakan sebuah pertemuan antara supervisor dengan guru yang telah sepakat untuk dilakukan pengamatan saat mengajar. Supervisi klinis dilakukan untuk memecahkan masalah-masalah pembelajaran sehingga dapat memperbaiki kelemahan guru dalam mengajar.Tahapan pelaksanaan supervisi klinis dalam bentuk siklus dimulai dengan kegiatan pra siklus, kemudian dilanjutkan pada tahap pertemuan pendahuluan, pengamatan (observasi) kelas, dan pertemuan balikan (Mukhtar, 2009: 63).

Mukhtar menambahkan bahwa mengajar merupakan suatu kegiatan yang dapat dikontrol melalui tiga kegiatan pokok supervisi klinis, yaitu pertemuan pendahuluan, pengamatan, dan pertemuan balikan yang mengacu pada pelaksanaan kegiatan mengajar tersebut. Jadi yang menjadi tujuan supervisi klinis secara umum adalah memperbaiki dan meningkatkan keterampilan guru dalam mengajar. Berdasarkan uraian latar belakang diatas, peneliti bermaksud untuk memecahkan masalah dalam penelitian ini yaitu apakah supervisi klinis dapat meningkatkan kemampuan guru SD dalam menyusun dan mengimplementasikan RPP.

\section{KAJIAN TEORI}

Proses pembelajaran merupakan suatu sistem yang dalam pencapaian tujuannya harus dimulai dari menganalisis setiap komponen yang mempengaruhinya. Dari sekian banyak komponen yang mempengaruhi pencapaian tujuan pembelajaran, terdapat satu komponen 
yang selama ini disebut-sebut sebagai komponen yang paling mempengaruhi. Komponen tersebut adalah guru. Guru disebut sebagai agen pembelajaran (learning agent) yang berperan sebagai fasilitator, motivator, pemacu, dan inovator bagi peserta didik.

Asumsi yang selama ini berkembang dimasyarakat adalah guru sebagai agen pembelajaran yang hanya sekedar menyampaikan materi pelajaran saja. Namun tidak sesederhana itu, guru bukan hanya sekedar menjadi agen penyampai materi pelajaran, namun lebih menekankan pada proses merubah tingkah laku peserta didik sesuai yang diharapkan. Oleh sebab itu, seorang guru perlu mempunyai kemampuan merancang dan mengimplementasikan pembelajaran sesuai dengan bakat, minat, perkembangan peserta didik, dan lingkungan belajar dengan menggunakan berbagai sumber dan media pembelajaran untuk menjamin efektivitas pembelajaran (Sanjaya, 2015: 274).

Hal itu sesuai dengan Undang-Undang No.14 Tahun 2005, bahwa guru harus memiliki kemampuan dalam pengelolaan pembelajaran yang sekurang-kurangnya meliputi perancangan pembelajaran dan pelaksanaan pembelajaran yang mendidik dan dialogis.

Kemampuan guru dalam pengelolaan pembelajaran tentunya dituntut agar kualitasnya selalu baik bahkan meningkat. Usaha yang dapat ditempuhuntukmemperbaiki danme-ningkatkan kemampuan guru dalam pengelolaan pembelajaran adalah melalui supervisi. Supervisi merupakan suatu upaya mengkoordinasi dan membimbing guru-guru di sekolah yang dilakukan secara berkelanjutan baik individu maupun kelompok (Mukhtar, 2009: 41). Kegiatan supervisi bertujuan untuk meningkatkan kemampuan profesionalis guru. Kemampuan profesional ini tercermin pada kemampuan guru dalam memberikan layanan pembelajaran, sehingga terjadi perubahan perilaku akademik bagi murid (Sagala, 2012: 95). Supervisi dilakukan bukan untuk mencari kesalahan guru, akan tetapi lebih untuk membantu guru memecahkan masalah yang dihadapi dalam menjalankan tugasnya (Kompri, 2015: 241).

Jenis supervisi yang cocok untuk mengatasi kelemahan-kelemahan guru dalam pengelolaan pembelajaran adalah supervisi klinis. Menurut Sagala (2012: 195) supervisi klinis merupakan suatu pendekatan melalui proses bimbingan dengan menyediakan konsultasi, dukungan, layanan dan bantuan kepada guru untuk meningkatkan kepro-fesionalannya melalui sejumlah tahapan yaitu observasi, implementasi pembelajaran, dan kegiatan diskusi hasil analisis data sebagai pegangan untuk perubahan tingkah laku, memperbaiki dan meningkatkan kualitas pembelajaran ke arah yang lebih baik.

Sejalan dengan pendapat Sagala, Mukhtar(2009: 60-61) mendefinisikan supervisi klinis adalah suatu proses bimbingan yang bertujuan untuk mengembangkan profesional guru dalam hal penampilan mengajar berdasarkan observasi dan analisis data sebagai pegangan untuk perubahan tingkah laku mengajar. Tidak berbeda jauh dengan pendapat Sagala dan Mukhtar, Purwanto (2010: 90) mendefinisikan supervisi klinis sebagai pengamatan yang dilakukan secara langsung terhadap cara guru mengajar, kemudian mengadakan "diskusi balikan" untuk memecahkan masalah yang dialami guru. Pidarta (2009: 124) menegaskan bahwa supervisi merupakan kegiatan pengamatan bagi guru yang betul-betul membutuhkan bantuan dikarenakan kinerjanya masih amat lemah, sehingga dengan adanya balikan yang diberikan supervisor dapat memperbaiki kelemahan guru mengajar.

Berdasarkan beberapa definisi supervisi menurut para ahli di atas, dapat dirumuskan bahwa supervisi merupakan (1) pengamatan 
yang dilakukan secara langsung terhadap cara guru mengajar; (2) penyediaan layanan dan bantuan untuk memecahkan masalah guru dalam pembelajaran; (3) umpan balik sebgai upaya untuk memperbaiki/meningkatkan kemampuan guru dalam mengajar.

Supervisi klinis adalah suatu proses bimbingan yang bertujuan untuk membantu pengembangan profesional guru, khususnya dalam menyiapkan dan penampilan mengajar, berdasarkan observasi dan analisis data secara teliti dan obyektif sebagai pegangan untuk perubahan tingkah laku mengajar tersebut. Supervisi klinis dilaksanakan secara berkesinambungan melalui tahapan pra-observasi, observasi pembelajaran, dan pasca observasi (Slamet Lestasi, Nurtanio Agus, \& Lia Yuliana, 2009: 12). Lebih lanjut dijelaskan bahwa pelaksanaan supervisi klinis dilakukan melalui 3 tahapan, yaitu tahap Pra-observasi, Observasi, dan Pascaobsevasi. Hal-hal yang perlu diperhati-kan pada tahap Pra-observasi, Observasi, dan Pascaobsevasi. Pada tahap Pra-observasi (Pertemuan awal): ciptakan suasana akrab dengan guru; Membahas persiapan yang dibuat oleh guru dan membuat kesepakatan mengenai aspek yang menjadi fokus pengamatan; dan menyepakati instrumen observasi yang akan digunakan. Pada tahap Observasi, sebaiknya memperhatikan halhal berikut: pengamatan difokuskan pada aspek yang telah disepakati; gunakan instrumen observasi; perlu dibuat catatan (fieldnotes); catatan observasi meliputi perilaku guru dan siswa; dan upayakan tidak mengganggu proses pembelajaran. Pasca-observasi (Pertemuan balikan), perhatikan hal-hal berikut: dilaksanakan segera setelah observasi; tanyakan bagaimana pendapat guru mengenai proses pembelajaran yang baru berlangsung; tunjukkan data hasil observasi (instrumen dan catatan) - beri kesempatan guru mencermati dan menganalisisnya; diskusikan secara terbuka hasil observasi, terutama pada aspek yang telah disepakati (kontrak) - Berikan penguatan terhadap penampilan guru. Hindari kesan menyalahkan. Usahakan guru menemukan sendiri kekurangannya; Berikan dorongan moral bahwagurumampumemperbaikikekurangannya; dan tentukan bersama rencana pembelajaran dan supervisi berikutnya.

Berkaitan dengan tindak lanjut supervisi ini, salah satu metode yang dapat digunakan oleh kepala sekolah selaku supervisor adalah meminta bantuan guru senior sebagai tutor sejawat untuk melakukan bimbingan atau pelatihan singkat. Berbagai penelitian menunjukkan bahwa pelatihan yang dilakukan oleh teman sejawat sebagai tutor terbukti lebih efektif. Ahmad Yusuf Sobri (2013) dalam penelitiannya mengatakan pelaksanaan supervisi tidak berjalan efektif apabila dilakukan hanya oleh kepala sekolah saja. Kepala sekolah melibatkan guru senior dalam kegiatan supervisi. Ternyata guru yang disupervisi lebih merasa terbantu karena keterlibatan guru senior membuat guru tidak ada hambatan psikologis dalam kegiatana supervisi. Kegiatan diskusi dan bertukar pengalaman untuk memecahkan masalah dapat berangsung lebih keluasa. Sejalan dengan pendapat Yusuf Sobri, K Ahmad juga mengemukakan bahwa dalam menangani persoalan-persoalan di kelas, guru dapat bekerja sama dengan teman sejawat/ sesama guru untuk berkolaborasi sehingga dapat menangani masalah di kelas dengan lebih baik dan terjadi penularan (transfer of learning) pengetahuan. Penelitian lain yang dilakukan oleh Kirbani, Budiyono, Susanto (2013) membuktikan bahwa penilaian yang dilakukan oleh teman sejawat dapat memberikan hasil yang lebih tinggi.

Berdasarkan rumusan permasalahan dan kajian teori di atas, dapat disusun hipotesis tindakan yaitu supervisi klinis dilanjutkan dengan bimbingan tutor sejawat mampu meningkatkan 
kemampuan guru dalam menyusun dan mengimplementasikan RPP.

\section{METODE PENELITIAN}

Penelitian ini merupakan penelitian tindakan sekolah, dilaksanakan di SDITAl-Fallah Kecamatan Simo, Kabupaten Boyolali. Pelakanaan penelitian ini dilakukan melalui tahap studi pendahuluan, penyusunan proposal penelitian, penyusunan instrumen, pengumpulan data, analisis data, pembahasan hasil analisis data, dan penyusunan laporan. Sampel sumber data dalam penelitian ini adalah 4 orang guru, dengan mengukur skor kemampuan guru dalam menyusun RPP dan skor kemampuan guru dalam mengajar.

Penelitian tindakan sekolah ini dilakukan menggunakan model supervisi klinik yang terdiri dari 2 siklus dimana setiap siklus terdapat 3 tahap. Supervisi ini diawali dengan mendiskusikan rencana pembelajaran antara supervisor dengan guru, dilanjutkan supervisor mengobservasi guru, menemukan permasalahan dan diakhiri dengan mendiskusikan cara memperbaikinya.

\section{Siklus I}

1. Perencanaan; Pada tahap ini supervisor bersama guru membicarakan rencana kemampuan yang akan diamati, teknik yang akan digunakan, sasaran dan pelaksanaan supervisi. Supervisor menyiapkan instrumen observasi dan lembar wawancara selanjutnya melakukan review RPP yang disusun oleh guru.

2. Pengamatan; Pada tahap ini guru melatih tingkah laku mengajar sesuai kesepakatan sebelumnya. Supervisor melakukan pengamatan tentang perilaku guru yang sedang mengajar sambil mencatat hasil pengamatan.

3. Pertemuan balikan; Supervisor bersama guru berdiskusi melakukan analisa dan refleksi hasil pengamatan perilaku guru mengajar. Balikan diberikan dengan segera dan secara objektif.

Siklus II

1. Perencanaan; Pada tahap ini supervisor bersama guru membicarakan rencana kemampuan yang akan diamati, teknik yang akan digunakan, sasaran dan pelaksanaan supervisi. Supervisor menyiapkan instrumen observasi dan lembar wawancara. Berdasarkan hasil analisa dan refleksi pada siklus I, supervisor melakukan review dokumen pembelajaran meliputi silabus dan RPP.

2. Pengamatan; Supervisor melakukan pengamatan kembali tentang perilaku guru dalam mengimplementasikan RPP sambil mencatat hasil pengamatan.

4. Pertemuan balikan; Supervisor bersama guru berdiskusi melakukan analisa dan refleksi hasil pengamatan perilaku guru mengajar. Balikan diberikan dengan segera dan secara objektif. Balikan diteruskan dengan melakukan tindakan berupa pelatihan yang dilakukan oleh tutor sejawat.

Teknik pengumpulan data dalam penelitian ini adalah wawancara tidak terstruktur dan observasi terstruktur menggunakan lembar penilaian yang terdiri dari 7 item untuk menilai RPP yang disusun guru dan 24 item untuk menilai pelaksanaan pembelajaran. Observasi terstruktur, dilengkapi dengan instrumen observasi yang digunakan untuk mengetahui skor kemampuan guru dalam menyusun RPP dan dalam melakukan pembelajaran. Teknik wawancara tidak terstruktur dilakukan ketika melakukan studi pendahuluan untuk mengetahui kebutuhan/ masalah yang dialami guru.

Tahap selanjutnya setelah data terkumpul, dilanjutkan dengan analisis data. Analisis data pada penelitian ini menggunakan analisis deskriptif kategoris dan komparatif melalui 
perbandingan skor rata-rata kemam-puan guru dalam menyusun RPP dan kemam-puan guru dalammelakukan pembelajaran pada siklus Idan siklus II. Hasil pengukuran kemam-puan guru merancang RPP dan melaksanakan pembelajaran dikategorikan menjadi limakategori berikut: skor $\geq 80=\mathrm{SB}$ (Sangat Baik); $60-79=$ Baik (B); $40-59=$ Kurang Baik (KB); $20-39=$ Jelek $(\mathrm{J}) ;<20=$ Sangat Jelek (SJ). Selanjutnya hasil komparasi skor kompetensi guru merancang RPP dan melaksanakan pembelajaran dibandingkan dengan kriteria keberhasilan PTS berikut: 1) pada Siklus I, PTS dikatakan berhasil jika persentase kenaikan skor kompetensi guru dalam merancang RPP dan melaksanakan pembelajaran mencapai $\geq 30 \%$; 2) Pada Siklus II, PTS dikatakan berhasil jika persentase kenaikan skor kompetensi guru dalam merancang RPP dan melaksanakan pembelajaran mencapai $\geq 25 \%$.

\section{HASIL DAN PEMBAHASAN}

\section{Hasil Penelitian}

Penelitian ini dilaksanakan sesuai rancangan yang telah ditetapkan, yaitu terdiri dari dua siklus (siklus I dan siklus II) dapat dipaparkan sebagai berikut. Pada Siklus 1, kegiatan perencanaan secara umum guru mampu menyusun RPP dengan baik, namun masih ditemukan beberapa kelemahan misalnya pada aspek kerincian skenario pembelajaran dan kesesuaian teknik dengan tujuan pem-belajaran. Pada aspek tersebut, terdapat guru yang mendapatkan skor 1 .

Pada tahap pelaksanaan pembelajaran, hasil pengamatan menunjukkan bahwa secara umum perilaku guru yang ditampilkan ketika mengimplementasikan RPP, ditemukan beberapa kelemahan dalam hal penguasaan kelas, menumbuhkan kebiasaan positif siswa, melibatkan siswa dalam pemanfaatan media pembelajaran. Pertemuan balikan untuk refleksi,
Kepala Sekolah selaku supervisor berdiskusi dengan guru mencoba untuk memecahkan masalah yang dialami guru. Upaya yang dilakukan untuk memecahkan masalah yang dialami guru, dilakukan menggunakan pendekatan humanistik teknik tutor sejawat. Pada siklus ini supervisor sekaligus berperan sebagai tutor sejawat yang memberikan masukan terhadap guru dan memecahkan masalah yang dialami guru.

Pada Siklus II, kegiatan perencanaan secara umum menunjukkan bahwa kemampuan guru dalam menyusun RPP sudah lebih baik dibandingkan pada siklus I, hal tersebut tercermin pada skor penilaian perencanaan dimana sudah tidak ada guru yang mendapatkan skor 1 pada aspek tertentu.

Pada tahap pengamatan pelaksanaan pembelajaran, perilaku guru yang ditampilkan ketikamengimplementasikan RPP sudahnampak adanya peningkatan yang jelas. Hal tersebut diperkuat dengan skor penilaian pelaksanaan pembelajaran dimana skor guru berada pada skor 4 dan 5. Pada pertemuan balikan, berdasarkan hasil analisa pengamatan yang dilakukan oleh supervisor, terlihat adanya peningkatan guru dalam menyusun dan mengimplementasikan RPP. Walaupun belum semua guru memperoleh skor 5 .

Secara rinci data temuan penelitian ayng menunjukkan adanya peningkatan kemampuan guru dalam menyusun dan mengimplementasikan RPP dapat dilihat pada tabel 1. Berdasarkan data pada tabel 1, diperoleh beberapa temuan. Temuan yang pertama, Temuan yang pertama, pada kondisi awal diperoleh skor kompetensi guru dalam menyusun rencana pembelajaran bergerak antara 55 sampai 65 , dengan rerata sebesar 59,37, berada pada rentang skor 40 - 59, berarti berada pada kategori kurang baik (KB). Hal ini disebabkan karena guru belum mampu memenuhi rambu- 
Tabel 1 Komparasi Skor Kemampuan Guru dalam menyusun RPP dan melaksanakan pembelajaran

\begin{tabular}{lcccccc}
\hline \multirow{2}{*}{ Nama } & \multicolumn{2}{c}{ Kondisi Awal } & \multicolumn{2}{c}{ Siklus I } & \multicolumn{2}{c}{ Siklus II } \\
\cline { 2 - 7 } & $\begin{array}{c}\text { Peren- } \\
\text { canaan }\end{array}$ & $\begin{array}{c}\text { Pelak- } \\
\text { sanaan }\end{array}$ & $\begin{array}{c}\text { Peren- } \\
\text { canaan }\end{array}$ & $\begin{array}{c}\text { Pelak- } \\
\text { sanaan }\end{array}$ & $\begin{array}{c}\text { Peren- } \\
\text { canaan }\end{array}$ & $\begin{array}{c}\text { Pelak- } \\
\text { sanaan }\end{array}$ \\
\hline IK & 65 & 68,3 & 80 & 78 & 95 & 96 \\
AD & 60 & 59,1 & 73 & 74 & 94 & 96 \\
RD & 55 & 57,5 & 69,1 & 80 & 90 & 98 \\
S & 57,5 & 58,3 & 75 & 75 & 94 & 95 \\
\hline Rerata & 59,37 & 60,8 & 74,27 & 76,75 & 93,25 & 96,25 \\
Selisih Rerata & & & 14,9 & 15,95 & 18,97 & 19,5 \\
Peningkatan (\%) & & & 25 & 26 & 26 & 25 \\
Indikator Keberhasilan (\%) & & 30 & 30 & 25 & 25 \\
\hline
\end{tabular}

rambu penyusunan RPP yang baik dan benar dari Kemendikbud, yang digunakan guru sebagai pedoman mengajar merupakan RPP, sehingga guru kurang memahami bagaimana penyusunan yang sesuai dengan karakteristik siswa yang hadapi. Tindakan yang dilakukan supervisor untuk mengatasi masalah tersebut adalah dengan memberikan penjelasan dan bimbingan mengenai cara menyusun RPP dengan baik dan benar sesuai dengan karakteristik siswa yang dihadapi.

Pada Siklus I diperoleh skor kompetensi guru dalam menyusun rencana pembelajaran bergerak antara 69,1 sampai 80 dengan rerata sebesar 74,27. Rerata ini berada pada rentang skor60 - 79, berarti berada pada kategori baik (B). Pada Siklus II diperoleh skor kompetensi guru dalam menyusun rencana pembelajaran bergerak antara 90 sampai 95 dengan rerata sebesar 93,25. Rerata ini berada pada rentang skore $\geq 80$, berarti berada pada kategori sangat baik (SB).

Temuan yang kedua, pada kondisi awal diperoleh skor kompetensi guru dalam melaksanakan pembelajaran bergerak antara 57,5 sampai 68,3 , dengan rerata sebesar 58,3, berada pada rentang skor $40-59$, berarti berada pada kategori kurang baik (KB). Hal ini disebabkan karena guru belum mampu melaksanakan sintak model pembelajaran dengan baik. Adapun penyebab yang mengakibatkan guru belum mampu melakukan pembelajaran dengan baik, dikarenakan guru bulum terbiasa menggunakan model pembelajaran berdasarkan sintak tertentu, sehingga guru mengalami kesulitan dalam melaksanakannya. Treatmen yang diberikan kepala sekolah selaku supervisor kepada guru untuk memecahkan masalah tersebut adalah memberikan bimbingan/tutor sejawat sesuai kebutuhan masing-masing guru.

Pada Siklus I diperoleh skor kompetensi guru dalam melaksanakan pembelajaran bergerak antara 74 sampai 80 dengan rerata sebesar 76,75. Rerata ini berada pada rentang skor60 - 79, berarti berada pada kategori baik (B). Pada Siklus II diperoleh skor kompetensi guru dalam melaksanakan pembelajaran bergerak antara 95 sampai 98 dengan rerata sebesar 96,25 . Rerata ini berada pada rentang skor $\geq 80$, berarti berada pada kategori sangat baik (SB). Komparasi rerata kompetensi guru secara visual dapat dilihat pada gambar 1 .

Berdasarkan paparan data tersebut di atas, nampak bahwa terjadi peningkatan persentase skor kompetensi guru dalam menyusun RPP sebesar $25 \%$ pada Siklus I dan $26 \%$ pada Siklus II. Demikian juga terjadi peningkatan persentase skor kemampuan guru dalam melaksanakan pembelajaran sebesar $26 \%$ pada 


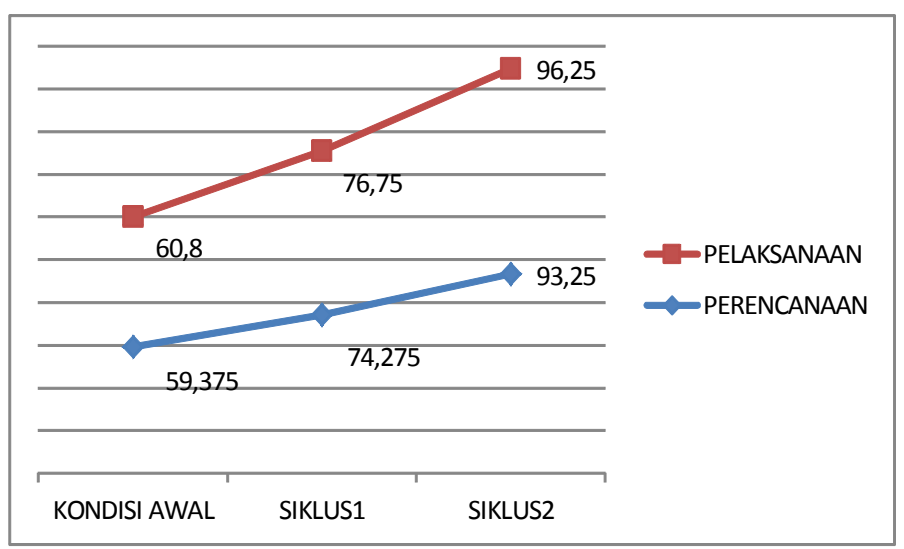

Gambar 1 Grafik visualisasi komparasi skor rerata kompetensi guru dalam menyusun RPP dan melaksanakan pembelajaran

Siklus I dan $25 \%$ pada Siklus II.Temuan data hasil penelitian ini jika dibandingkan dengan kriteria keberhasilan PTS, nampak bahwa tindakan pada Siklus I belum berhasil (persentase peningkatan baru mencapai $25 \%$, padahal kriteria keberhasilannya adalah 30\%). Kegagalan tindakan pada Siklus I ini menjadi bahan refleksi kepala sekolah sebagai supervisor untuk memperbaiki tindakan Siklus II dengan mengintensifkan peran teman sejawat sebagai tutor, melalui contoh-contoh konkrit dan peer teaching.Perbaikan tindakan ini menampakkan hasil, terbukti pada Siklus II persentase peningkatan kompetensi guru dalam menyusun RPP dan melaksanakan pembelajaran mencapai kriteria keberhasilan. Terlihat bahwa persentase kenaikan skor kompetensi menyusun RPP mencapai 26\% (lebih tinggi dari kriteria keberhasilan 25\%). Demikian juga dengan capaian persentase kenaikan skor kemampuan melaksanakan pembelajaran mencapai 25\% (sama dengan kriteria keberhasilan 25\%).

\section{Komparasi Distribusi Frekuensi Skor Kemampuan Guru dalam menyusun RPP}

Peningkatan kemampuan guru dalam menyusun RPP dapat dikomparasikan dari kondisi awal, siklus I, dan siklus II. Data komparasi dapat dilihat pada Tabel 2.
Tabel 2 Komparasi Distribusi Frekuensi Skor Kemampuan Guru dalam menyusun RPP

\begin{tabular}{cccc}
\hline $\begin{array}{c}\text { Kelas } \\
\text { Interval }\end{array}$ & $\begin{array}{c}\text { Kondisi } \\
\text { Awal }\end{array}$ & Silus1 & Siklus2 \\
\hline$<\mathbf{2 0}$ & 0 & 0 & 0 \\
$\mathbf{2 0}-\mathbf{3 9}$ & 0 & 0 & 0 \\
$\mathbf{4 0 - 5 9}$ & 1 & 0 & 0 \\
$\mathbf{6 0 - 7 9}$ & 1 & 3 & 0 \\
$\geq \mathbf{8 0}$ & 2 & 1 & 4 \\
\hline
\end{tabular}

\section{Komparasi Distribusi Frekuensi Skor Kemampuan Guru dalam melaksanakan pembelajaran}

Sama seperti halnya komparasi distribusi frekuensi kemampuan guru dalam menyusun RPP, peningkatan kemampuan guru dalam melaksanakan pembelajaran dapat dikomparasikan dari kondisi awal, siklus I, dan siklus II. Data komparasi dapat dilihat pada Tabel 3.

Tabel 3 Komparasi Distribusi Frekuensi Skor Kemampuan Guru Dalam melaksanakan pembelajaran

\begin{tabular}{cccc}
\hline $\begin{array}{c}\text { Kelas } \\
\text { Interval }\end{array}$ & $\begin{array}{c}\text { Kondisi } \\
\text { Awal }\end{array}$ & Siklus1 & Siklus2 \\
\hline$<\mathbf{2 0}$ & 0 & 0 & 0 \\
$\mathbf{2 0}-\mathbf{3 9}$ & 0 & 0 & 0 \\
$\mathbf{4 0}-\mathbf{5 9}$ & 1 & 0 & 0 \\
$\mathbf{6 0}-\mathbf{7 9}$ & 1 & 3 & 0 \\
$\mathbf{2} \mathbf{8 0}$ & 2 & 1 & 4 \\
\hline
\end{tabular}




\section{Uji Perbedaan Kemampuan Guru dalam Menyusun RPP dan Melaksanakan Pembelajaran}

Perbedaan kemampuan guru dalam menyusun RPP dan dalam melaksanakan pembelajaran telah dijelaskan secara deskriptif pada bagian sebelumnya, namun belum bisa diketahui apakah signifikan atau tidak. Untuk mengetahui signifikan tidaknya perbedaan tersebut maka dilakukan uji statistik menggunakan uji t untuk melihat perbedaan skor kemampuan guru pada siklus I dan siklus II. Data hasil uji perbedaan menggunakan uji $\mathrm{t}$ dapat dilihat pada Tabel 4 dan Tabel 5.

Dari Tabel 4, tampak bahwa perbedaan kemampuan guru dalam menyusun RPP pada kondisi awal, siklus 1, dan siklus 2 terlihat dari t hitung sebesar 8,124 dengan probabilitas sebesar 0,000 . Oleh karena probabilitas lebih kecil dari $\alpha(0,05)$, maka perbedaan ini signifikan.

Dari Tabel 5, tampak bahwa perbedaan kemampuan guru dalam melaksanakan pembelajaran kondisi awal, siklus I, dan siklus
II terlihat dari t hitung sebesar 8,124 dengan probabilitas sebesar 0,000 . Oleh karena probabilitas lebih kecil dari $\alpha(0,05)$, maka perbedaan ini signifikan.

Temuan penelitian ini sejalan dengan penelitian terkini yang dilakukan oleh Amani dkk (2013), Sulthoni Akhmad dkk (2014), Karniti (2014) yang menyatakan bahwa kegiatan supervisi klinis mampu meningkatkan kemampuan guru dalam menyusun RPP dan melaksanakan pembelajaran. Penelitian senada dilakukan oleh I Wayan Korma (2012), bahwa terdapat pengaruh yang signifikan implementasi pendekatan supervisi klinis secara simultan terhadap wawasan kompetensi pedagogik dan kualitas guru dalam pengelolaan pembelajaran. Penelitian Sri Hidayati (2012) menunjukkan adanyapengaruh positifdan signifikan pelaksanaan supervisi klinis kunjungan kelas terhadap kompetensi profesional gurumata pelajaran UN.

Keberhasilan tindakan ini terlihat bahwa setelah guru diberikan bantuan berupa bimbingan/tutor sejawatmelalui supervisi klinis,

Tabel 4 Hasil Uji Perbedaan Kemampuan Guru dalam Menyusun RPP

\begin{tabular}{lcccccc} 
& \multicolumn{8}{c}{ One-Sample Test } \\
\cline { 2 - 7 } & $\mathrm{t}$ & $\mathrm{df}$ & $\begin{array}{c}\text { Sig. } \\
(2-\text {-tailed) }\end{array}$ & $\begin{array}{c}\text { Mean } \\
\text { Difference }\end{array}$ & \multicolumn{2}{c}{$\begin{array}{c}\text { 95\% Confidence Interval } \\
\text { of the Difference }\end{array}$} \\
\cline { 2 - 7 } & & & & & Lower & Upper \\
\cline { 2 - 7 } $\begin{array}{c}\text { Penyusunan } \\
\text { rpp }\end{array}$ & 8,124 & 11 &, 000 & 2,000 & 1,46 & 2,54 \\
\hline skor & 17,560 & 11 &, 000 & 79,850 & 69,84 & 89,86 \\
\hline
\end{tabular}

Tabel 5 Hasil Uji Perbedaan Kemampuan Guru dalam Melaksanakan Pembelajaran

\begin{tabular}{lcccccc} 
& \multicolumn{8}{c}{ One-Sample Test } \\
\cline { 2 - 7 } & $\mathrm{t}$ & $\mathrm{df}$ & $\begin{array}{c}\text { Sig. } \\
(2 \text {-tailed) }\end{array}$ & $\begin{array}{c}\text { Mean } \\
\text { Difference }\end{array}$ & $\begin{array}{c}\text { 95\% Confidence Interval } \\
\text { of the Difference }\end{array}$ \\
\cline { 2 - 7 } Pelaksanaan & 8,124 & 11 &, 000 & 2,000 & 1,46 & 2,54 \\
\hline skor & 17,951 & 11 &, 000 & 81,917 & 71,87 & 91,96 \\
\hline
\end{tabular}


guru mampu menyusun rencana pelaksanaan pembelajaran dengan tepat sesuai dengan karakteristik siswa yang dihadapi. Hal ini sesuai dengan amanat Permendiknas No. 41 Tahun 2007 tentang standar proses, bahwa pelaksanaan proses pembelajaran harus direncanakan, dilaksanakan, dinilai, dan diawasi agar pembelajaran berlangsung dengan efektifdan efisien. Bimbingan atau bantuan yang diberikan kepada guru disesuaikan dengan kebutuhan guru yang berhubungan dengan tugasnya yaitu mengajar. Hal ini sesuai dengan prinsip supervisi klinis yaitu pengkajian objek berdasarkan pada kebutuhan profesional guru secara nyata/ yang dialami (Mukhtar, 2009: 62).

\section{SIMPULAN DAN SARAN}

\section{Simpulan}

Berdasarkan hasil analisis data dan pembahasan, dapat ditarik dua simpulan yaitu supervisi klinis mampu meningkatkan kemampuan guru dalam menyusun rencana pembelajaran di SDITAl-Fallah, Kecamatan Simo, Kabupaten Boyolali sebesar 26\%. Simpulan selanjutnya bahwa supervisi klinis mampu meningkatkan kemampuan guru dalam melaksanakan pembelajaran di SDITAl-Fallah, Kecamatan Simo, Kabupaten Boyolali sebesar $25 \%$.

\section{Saran}

Mengacu pada simpulan PTS ini penulis menyaranlan hendaknya kepala sekolah melakukan supervisi klinis terhadap guru-guru secara kontinyu, sehingga dapat memperbaiki kelemahan-kelemahan guru dalam mengajar bahkan meningkatkan kualitas pembelajaran. Saran berikutnya hendaknya guru selalu bersikap proaktif terhadap treatment kepala sekolah yang bertujuan untuk memperbaiki kualitas pembelajaran.

\section{DAFTAR PUSTAKA}

Ahmad Yusuf Sobri. 2013. Pembinaan Profesionalisme Guru Dalam Meningkatkan Kualitas Pembelajaran. Jurnal Manajemen Pendidikan Universitas Negeri Malang 23 (1): 15 - 28.

I Wayan Korna. 2012. Pengaruh Implementasi Pendekatan Supervisi Klinis Terhadap Wawasan Kompetensi Pedagogik dan Kualitas Pengelolaan Pembelajaran para Guru di Gugus IV SD Kecamatan Denpasar Selatan. Jurnal Penelitian Pascasarjana UNDIKSHA. Vol. 2 (2): 1-12

K Ahmad. 2009. Penelitian Tindakan Kelas. Jurnal Pendidikan Penabur 8 (12): 5365 .

Karniti. 2014.Supervisi Klinis dengan Pendekatan "PIS" sebagai Upaya Peningkatan Kualitas Pembelajaran Guru. Jurnal Penelitian Tindakan Sekolah dan Kepengawasan. 1 (2): 1-7.

Kirbani, Budiyono, dan Sutanto. 2013. Pengembangan Model Assessment For Learning (Afl) Melalui Penilaian Teman Sejawat Untuk Pembelajaran Matematika pada Pokok Bahasan Persamaan Garis Lurus di Madrasah Tsanawiyah Pondok Pesantren Modern Islam Assalaam Sukoharjo. eprints.uns.ac.id (2): 131-143.

Kompri. 2015. Manajemen Sekolah Orientasi Kemandirian Kepala Sekolah. Jogyakarta: Pustaka Pelajar.

LuhAmani, Nyoman Dantes, Wayan Lasmawan. 2013. Implementasi Supervisi Klinis dalam Rangka Meningkatkan Kemampuan Guru Mengelola Proses Pembelajaran pada Guru SD se-Gugus VII Kecamatan Sawan. e-Journal Program Pascasarjana Universitas Pendidikan 
Ganesha Jurusan Pendidikan Dasar. 3 (1): 12-23

Mukhtar dan Iskandar. 2009. Orientasi Baru Supervisi Pendidikan. Jakarta: GP Press.

Permendiknas Nomor 41 Tahun 2007 Tentang Standar Proses.

Pidarta, Made. 2009. Supervisi Pendidikan Kontekstual. Jakarta: Rineka Cipta.

Purwanto, Ngalim. 2010. Administrasi dan Supervisi Pendidikan. Bandung: Remaja Rosdakarya.

Sagala, Syaiful. 2010. Supervisi Pembelajaran dalam Profesi Pendidikan. Bandung: Alfabeta.

Sanjaya. 2015. Kurikulum dan Pembelajaran. Jakarta: Kencana.

Sartiti, Kendarti. 2014. Peningkatan Kemampuan Guru Mipa dalam Mengembangkan Instrumen Penilaian Kelas Melalui Supervisi Klinis di Sekolah Binaan.Jurnal Ilmiah Guru “COPE”, 1 (18):11-18.
Slamet Lestasi, Nurtanio Agus, \& Lia Yuliana. 2009. Pelatihan Supervisi Klinis Bagi Kepala Sekolah Dasar Di Lingkungan Cabang Dinas Pendidikan Kecamatan Pleret Kabupaten Bantul. Yogyakarta: Fakultas Ilmu Pendidikan - Universitas Negeri Yogyakarta.

Sri Hudayati. 2012. Keikutsertaan dalam Kegiatan MGMP, Supervisi Klinis Kunjungan Kelas, In-Service Training, dan Kompetensi Profesional Guru SMP Negeri Sub Rayon 04 Jakenan Pati. Jurnal Manajemen Pendidikan. 7 (1): 73-82

Sugiyono. 2013. Metode Penelitian Manajemen. Yogyakarta:Alfabeta.

Sulthoni, Akhmad dkk. 2014. Pengembangan Model Supervisi Klinis dengan Pendekatan Lesson Study untuk Meningkatkan Kompetensi Profesional Guru Bahasa Inggris SMA Negeri di Kabupaten Cilacap. e-Journal of Educational Research and Evaluation. $3(1): 8-17$ 